\title{
STUDY OF FERTILIZER (ORGANIC + INORGANIC) FORMULATION TO IMPROVE GUBAL AGARWOOD FORMATION IN KETIMUNAN TREE (Gyrinops versteegii)
}

\author{
I Made Mega* and A.A. Nyoman Supadma \\ Department of Agroecotechnology, Agriculture Faculty, Udayana University Denpasar \\ *Corresponding author:mega_made@yahoo.com
}

\begin{abstract}
A study of fertilizer formulation (organic + inorganic) to increase the formation of sapwood (gubal) on agarwood plants (Gyrinops versteegii), had done to find the best fertilizer formulation that capable of increase and accelerate either growth and agarwood formation of sapwood on agarwood trees. The first year of study was conducted in Marga Tabanan Village. The field research was Randomized Block Designed (3 groups) with single factor of treatment. The tested treatment were 6 formulation of compound fertilizers and a control (unfertilized treatment). The compound fertlizers consisted of urea, SP-36, $\mathrm{KCl}$, local compost, and dolomite in varying doses. The fertilizer formulations were applied on 21 agarwood trees that previously inoculated with mixed inoculant of Fusarium solani and Rhisopus sp. Three months after inoculation, the data from the following parameters were measured and statistically analyzed: plant height, stem circumference, sapwood weight, resin content and soil chemical properties. The results showed that the tested fertilizer compound had significant effect on plant height, sapwood weight, and resin rendement. No significant effect of fertilizer compound measured on the stem circumference. The highest sapwood weights was obtained on $\mathrm{C}$ treatment (14.39 g). The highest resin yield was obtained on B treatment (3.91\%) which was relatively the same as that on C treatment $(3.85 \%)$. Thus, the best fertilizer formulation for either plant growth, agarwood formation or agarwood resin was C treatment $(100 \mathrm{~g}$ urea $+100 \mathrm{~g} \mathrm{SP}-36+100 \mathrm{~g} \mathrm{KCl})+$ $(7.5 \mathrm{~kg}$ compost $)+(75 \mathrm{~g}$ Dolomite $)$ per tree.
\end{abstract}

Keywords: fertilizer formulations (organic + inorganic), agarwood sapwood

\section{INTRODUCTION}

Agarwood plant (Gyrinops versteegii)

is a high-value commodity of non-timber forest products (HHBK), classified as an export commodity and a potential source of income for the community (Pasaribu et al., 2013). Therefore, Indonesian government has considered to include agarwood plants into national commodities of non-timber forest sustainable products (Santosa, 2009). The export volume of agarwood from Indonesia since 2000-2002 only reached 30 tons priced at USD 600.000. Agarwood are used for many purposed including perfume, cosmetics, medicines and for religious ritual purposes so that their worldwide needs continuous increasing (Tarigan, 2004). However, the production of Indonesia's 
agarwood is relatively low and decreasing with an average production of about 45 tons per year. The decline of agarwood production probably due to the relative high intensity harvesting of natural agarwood, without sufficient conservation efforts. Thus, conservation and sustainability of agarwood production needs to be maintained in order to produce good quality of sapwood without relying solely on natural agarwood production.

The cultivation of agarwood in Indonesia has carried out in various regions such as West Nusa Tenggara, Java, Kalimantan, Papua, and Bali. Cultivation ofagarwood in Bali Province has been carried out since 2003 in the following districts: Tabanan, Bangli, and Buleleng (Susila and Mega, 2012). Unfortunately, agarwood cultivation mostly done on less fertile soils under impropper agriculture practices that lead to very low and slow growth and formation of sapwood.

Application of balanced fertilizer formation between organic, natural, and artificial fertilizers (inorganic) is important to increase the growth and formation of sapwoods on agarwood trees. Organic fertilizers have complete nutrients content in low quantities, but able to improve the physical and biological soil properties. Inorganic fertilizers capable of provide more nutrients and more readily available to plants, whereas natural fertilizers (dolomites) considered to be a very important sources of $\mathrm{Ca}$ and $\mathrm{Mg}$ for plants (Rosmarkam and Yuwono, 2002). The acceleration and increase of sapwoods formation on agarwood trees can be done through inoculation with mixed inoculant of Fusarium sp. and Rhisopus sp. (Mega et al., 2012). To obtain an appropriate and balanced organic or inorganic fertilizer formulation, then it is important to study the Formulation of fertilizer (organic + inorganic) to increase the formation of sapwood agarwood on Ketimunan tree (Gyrinops versteegii).

The results of this study would be suggested to the government (Forest Service) as the best fertilizer technology to improve the agarwood plant yield. The intensive use of fertilizer compound is expected to accelerate and enhance the formation of sapwoods, resin content and farmer's income.

\section{MATERIALS AND METHODS}

A field research had been conducted in farmer's agarwood field in Marga Dauhpuri Village, Marga Sub-district, Tabanan from June to October 2016. The materials being used were including: mature compost (compost Simantri), 21 of 5 months old agarwood trees, Fusarium sp, Rhisopus sp,plastisin, cotton, paper label, urea fertilizer, SP-36 and $\mathrm{KCl}$, as well as natural 
fertilizer Dolomite. The equipment's were used including $\mathrm{pH}$ stick, wood drill, hoe, sickle, stationery, plastic strap, and knife.

The study was designed using Randomized Block Design (RCB) 3 groups. The single factor treatment tested consisted of 7 fertilizer formulas applied on 21 agarwood plants. The tested fertilizer compounds per tree were:

$\mathrm{A}=$ without fertilizer (control)

$\mathrm{B}=(25 \%$ inorganic fertilizer $)+(100 \%$ compost $+(50 \%$ Dolomite $) .(50 \mathrm{~g}$ urea + $50 \mathrm{~kg} \mathrm{SP}-36+50 \mathrm{~kg} \mathrm{KCl}+10 \mathrm{~kg}$ compost) $+50 \mathrm{~g}$ Dolomite) .

$\mathrm{C}=50 \%$ inorganic fertilizer $+75 \%$ compost $)$

$+75 \%$ Dolomite. $(100 \mathrm{~g}$ urea $+100 \mathrm{~g}$ SP$36+100 \mathrm{~g} \mathrm{KCl})+(7.5 \mathrm{~kg}$ of compost $)+$ (75 g Dolomite).

$\mathrm{D}=(75 \%$ inorganic fertilizer $+50 \%$ compost $+75 \%$ Dolomite). (150 g urea $+150 \mathrm{~g}$ SP-36 $+150 \mathrm{~g} \mathrm{KCl})+5 \mathrm{~kg}$ of compost) +75 g Dolomite).

$E=100 \%$ inorganic fertilizer $+25 \%$ compost $+100 \%$ Dolomite) (200 g urea $+200 \mathrm{~g}$ $\mathrm{SP}-36+200 \mathrm{~g} \mathrm{KCl})+2.5 \mathrm{~kg}$ of compost +100 g Dolomite.

$\mathrm{F}=(200 \mathrm{~g}$ urea $+150 \mathrm{~g} \mathrm{SP}-36+150 \mathrm{~g} \mathrm{KCl})$ $+7.5 \mathrm{~kg}$ compost $)+100 \mathrm{~g}$ Dolomite.

$\mathrm{G}=(200 \mathrm{~g}$ urea $+100 \mathrm{~g} \mathrm{SP}-36+100 \mathrm{~g} \mathrm{KCl})$ $+7.5 \mathrm{~kg}$ compost $)+75 \mathrm{~g}$ Dolomite
The following parameters were measured three months after fertilizer application. The growth of agarwood and formation of sapwood measured based on plant height $(\mathrm{cm})$, stem circumference $(\mathrm{mm})$, agarwoodsapwoods weight $(\mathrm{g})$, and the level resin rendemen $(\%)$. The percentage of resin content was measured by extracting sapwood using each $150 \mathrm{ml}$ of $\mathrm{N}$ Hexane, Acetone and Methanol for 3 hours. The yield of the resin was calculated by dividing the weight of the extracted resin with the weight of extracted sapwood and multiply by 100 (Pasaribu et al., 2013). Measurements of soil chemical properties were performed for the following parameters:Soil $\mathrm{pH}$ using $\mathrm{pH}$ meter, DHL using Conductometer, CEC (NH4OAc extract pH 7), C-organic (Walkley and Black), total $\mathrm{N}$ content (macro kjeldhal), available-P (Spectrophotometer), and available-K (Flamephotometer) were analyzed in the Soil and Environment Laboratory of Agriculture Faculty, Udayana University. The data were statistically analyzed by ANOVA followed by Duncan's multiple Range test at 5\% level.

\section{RESULTS AND DISCUSSION}

The results showed that three months after application, fertilizer compounds significantly affected plant growth (plant height), sapwoods agarwood, and the rendementof agarwood resin (Table 1). The 
highest increase of plant height was obtained at G treatment $(200 \mathrm{~g}$ urea $+100 \mathrm{~g} \mathrm{SP}-36+$ $100 \mathrm{~g} \mathrm{KCl})+7.5 \mathrm{~kg}$ compost $)+75 \mathrm{~g}$ Dolomite per tree $(24.33 \mathrm{~cm})$. The value was significantly different compare to that on control (without fertilizer) which was reach $6,50 \mathrm{~cm}$. The value was significantly different to that on $\mathrm{E}$ treatment $(200 \mathrm{~g}$ urea + $200 \mathrm{~g} \mathrm{SP}-36+200 \mathrm{~g} \mathrm{KCl})+2.5 \mathrm{~kg}$ of compost $+100 \mathrm{~g}$ Dolomite per tree) ie (10.33 $\mathrm{cm})$, and F ((200 g urea $+150 \mathrm{~g} \mathrm{SP}-36+150$ $\mathrm{g} \mathrm{KCl})+7.5 \mathrm{~kg}$ compost $)+100 \mathrm{~g}$ Dolomite per tree) ie $6.33 \mathrm{~cm}$ (Table 2). The highest sapwood weight was obtained on the $\mathrm{C}$ treatment (14.39 g) which was relatively the same as that on D treatment (11.85 g). The highest resin yield was obtained on B treatment $(3.91 \%)$ but not significantly different compare to $\mathrm{C}$ treatment $(3.85 \%)$. The increase of resin rendement in $\mathrm{B}$ and $\mathrm{C}$ treatments compared to control (A) were $12.36 \%$ and $10.63 \%$ (Table 2 ), respectively.

Table 1. The signification effect of treatments on measured parameters in this study

\begin{tabular}{lll}
\hline No. & Parameters & Significations \\
\hline 1. & Plants height $(\mathrm{cm})$ & $*$ \\
2. & Stem circumference $(\mathrm{mm})$ & $\mathrm{ns}$ \\
3. & The weight of agarwood sapwood $(\mathrm{g})$ & $*$ \\
4. & Rendemen of agarwood resin $(\%)$ & $*$ \\
\hline
\end{tabular}

Note $: *=$ significant $\quad \mathrm{ns}=$ non significant

Compound fertilizers improved soil tested fertilizers. The same patterns were also chemical properties indicated by the increase measured on the levels of organic-C, total-N, of $\mathrm{pH}$ value and the content of N-total, available-P and available-K (Table 3 ). available-P and available-K on three months The application of fertilizer compounds of application. The highest content of $\mathrm{N}, \mathrm{P}$, had significant effect on plants height, and $\mathrm{K}$ were found on $\mathrm{B}$ treatment, in amount sapwood weight, and rendement of resin, but of $0.29 \%, 512.45 \mathrm{ppm}$, and 557.26 not to the growth of stem circumference. The ppm,respectively. The levels of N, P, K in highest increment of stem circumference and the B treatment were slightly higher than highest weight of sapwood were achieved on thaton C treatment with the consecutive C treatment $(25,67 \mathrm{~mm}$ and $14,39 \mathrm{~g}$, levels of $0.28 \%, 327.37 \mathrm{ppm}$, and 438.12 respectively). The best effect of $\mathrm{C}$ treatment ppm. The formulated fertilizer slightly on stem circumference and weight of increased soil $\mathrm{pH}(6.1)$ ton early neutral in all 
sapwood were possibly due to its effect on

improvement of soil chemical properties.

Table 2. The average effect of treatments on the increase of plants height, stem circumference, weight of sapwood, the rendemen of agarwood resin

\begin{tabular}{llrlll}
\hline No. & Treatments $\begin{array}{c}\text { the increase } \\
\text { of plants height } \\
(\mathrm{m})\end{array}$ & $\begin{array}{l}\text { the increase of } \\
\text { stem circumference sapwood } \\
(\mathrm{mm})\end{array}$ & $\begin{array}{c}\text { Reight of } \\
(\mathrm{g})\end{array}$ & $\begin{array}{c}\text { Renen } \\
\text { of agarwoodresin }\end{array}$ \\
\hline 1. & $\mathrm{~A}$ & $6,50 \mathrm{a}$ & $5,93 \mathrm{a}$ & $6,68 \mathrm{a}$ & $3,48 \mathrm{ab}$ \\
2. & $\mathrm{~B}$ & $14,83 \mathrm{ab}$ & $6,73 \mathrm{a}$ & $6,87 \mathrm{a}$ & $3,91 \mathrm{~b}$ \\
3. & $\mathrm{C}$ & $13,00 \mathrm{ab}$ & $25,67 \mathrm{a}$ & $14,39 \mathrm{~b}$ & $3,85 \mathrm{~b}$ \\
4. & $\mathrm{D}$ & $13,50 \mathrm{ab}$ & $12,83 \mathrm{a}$ & $11,85 \mathrm{ab}$ & $3,05 \mathrm{ab}$ \\
5. & $\mathrm{E}$ & $10,33 \mathrm{a}$ & $11,0 \mathrm{a}$ & $7,82 \mathrm{a}$ & $2,83 \mathrm{ab}$ \\
6. & $\mathrm{~F}$ & $6,33 \mathrm{a}$ & $23,33 \mathrm{a}$ & $10,74 \mathrm{a}$ & $2,19 \mathrm{ab}$ \\
7. & $\mathrm{G}$ & $24,33 \mathrm{~b}$ & $16,00 \mathrm{a}$ & $7,69 \mathrm{a}$ & $1,35 \mathrm{a}$ \\
\hline
\end{tabular}

Note : The value on the same column followed by the same letter indicated statistically insignificant according to Duncan's Multiple Test on 5\%

Table 3. The effect of treatments on selected soil chemical properties measured on this study on three months following treatments on agarwood cultivation

\begin{tabular}{|c|c|c|c|c|c|c|}
\hline No. & Treatments & $\mathrm{pH}$ & $\begin{array}{c}\text { Org-C } \\
(\%)\end{array}$ & $\begin{array}{c}\text { Total-N } \\
(\%)\end{array}$ & $\begin{array}{l}\text { Available-P } \\
\quad(\mathrm{ppm})(\mathrm{ppm})\end{array}$ & Available-K \\
\hline 1. & A & 6,3 & 3,06 & 0,19 & 73,12 & 154,34 \\
\hline 2. & B & 6,5 & 4,32 & 0,29 & 512,45 & 557,26 \\
\hline 3. & $\mathrm{C}$ & 6,7 & 3,46 & 0,28 & 327,37 & 438,12 \\
\hline 4. & $\mathrm{D}$ & 6,8 & 4,51 & 0,22 & 235,86 & 312,57 \\
\hline 5. & $\mathrm{E}$ & 6,7 & 4,56 & 0,21 & 247,49 & 328,88 \\
\hline 6. & $\mathrm{~F}$ & 6,7 & 4,67 & 0,23 & 337,28 & 379,56 \\
\hline 7. & $\mathrm{G}$ & 6,5 & 4,75 & 0,24 & 408,19 & 512,53 \\
\hline 8. & Initial Soil & 6,1 & 3,04 & 0,19 & 69,45 & 138,77 \\
\hline
\end{tabular}

Soil receiving $\mathrm{C}$ treatment had nearly neutral $\mathrm{pH}$ (6.7), high organic-C content (3.46\%), moderate total soil $\mathrm{N}(0.28 \%)$, and both very high available $\mathrm{P}$ and $\mathrm{K}$ (327.37 ppm and $438.12 \mathrm{ppm}$, respectively). This finding wasin accordance with Erfandi and good conditions for the development of
Kasno (2000) which was stating that soil chemical properties greatly increase the growth of plants, stem circumference, and plant height. Increased growth of agarwood plant and stem circumference will provide 
Fusarium solani and Rhisopus sp. in infecting the agarwood trees, so that sapwoods development were increased and reached the highest weight on $\mathrm{C}$ treatment (14.39 g). Susila and Mega (2012) published that NPK fertilizer as much as $0.30 \mathrm{~kg}$ per tree and composted bokhasi as much as 5.0 $\mathrm{kg}$ to $7.5 \mathrm{~kg}$ per tree significantly increased plant height and agarwood stems circumference. Setyorini et al. (2003) mentions that the concept of balanced fertilization aimed to determine the optimal dosage of fertilizer based on the level of soil fertility and nutrients required by plants. C treatment provides the best nutrient balance derived from organic and inorganic fertilizers, thereby promoting the highest plant height and stem circumference of agarwood trees.

The formation of sapwood is determined by agarwood infection by Fusarium solani and Rhisopus sp. which was inoculated at some points on the stems of agarwood plant. Mixture of Fusarium solani and Rhisopus sp. developed the best sapwood on agarwood trees (Mega et al.,2012). In this research, the highest of sapwood formation was found on $\mathrm{C}$ treatment $(14,39 \mathrm{~g})$. C treatment promoted stem circumference and facilitated the development of extensive and intensive infection of agarwood stems by Fusarium solani and Rhisopus sp. and followed by forming the highest weight of sapwood. Sapwood Agarwood contains furan compounds and ester groups that can be measured from the formation of agarwood resin extract (Pasaribu et al., 2013). The highest resin content of agarwood in this study was obtained in B treatment $(3.91 \%)$ but it was relatively the same as the resin content of onC treatment (3.85\%). The formation of sapwood and agarwood resin was strongly supported by the higher content of available nutrients in soil caused by $\mathrm{C}$ treatment. The $\mathrm{C}$ treated soil had moderate content oftotal-N and very high availability of $\mathrm{P}$ and $\mathrm{K}$ which were higher than other treatments. This finding supported the opinion of Affandi et al. (2003). Development of good and high quality of sapwood can be indicated by the color change of sapwood from light brown to dark brown and blackish. In addition, good quality of agarwood sapwood can be known from the fragrant aroma because of the high resin rendement containing furan compounds, and other ester groups (Pasaribu, et al., 2012).

\section{ACKNOWLEDGEMENT}

Special thanks deliberate to the Rector of Udayana University for the grant and permit given, so this research can successfullyhad done. This research was funded by PNBP of Udayana University through Udayana Unggulan scheme with contract number 641- 
42/UN14.2/PNL.01.03.00/2016. Thanks also goes to Dr. Ir. Anak Agung Istri Kesumadewi, M.Si for her assistance in preparing the English version of this manuscript.

\section{REFERENCES}

Erfandi, D., \& Kasno, A. (2000). The Effectiveness of Inorganic and Organic Fertilizer Use to Increase Soil Productivity on Acid dry land. Proceedings of HITI. VII. Bandung.

Mega, I. M., Suanda, D. W., Kasniari, D. N., Suena, W., \& Parwata, M. O. (2012). Formulation of Inoculant Fungus Forming Agarwood Ingredients on Ketimunan Plant (Gyrinops versteegii). J. Agrotrop, 2(2), 139-144.

Pasaribu, G., Waluyo, T. K., \& Pari, G. (2013). Analysis of Chemical Components of Some Quality of Agarwood by Gas Mass Spectrometry Chromatography. J. Forest Product Research, 31 (3), 181-185.

Rosmarkam, A., \& Yuwono, N. W. (2002). Science of Soil Fertility .Kanisius Publisher.Yogyakarta.

Santosa, H. (2009). Conservation and Utilization of Agarwood. Presented in the National Seminar I Agarwood. Bogor.

Setyorini, D., Adiningsih, J. S., \& Rohayati, S. (2003). Soil Test as the Basic Formulation of Fertilization Recommendation. Soil Research Institute. Bogor.

Susila, D., \& Mega, I. M. (2012). Application of Balanced Fertilizer for Increasing Agarwood Growth Rate (Gyrinops verstegii) in Tabanan District. J.Agrotrop, 2(1), 10-16.

Tarigan, K. (2004). Profile of Cultivation (Farming) Agarwood. Ministry of Forestry. Forestry Counseling Center. Jakarta. 